\title{
Praxe participativních rozpočtů v České republice. Př́padová studie obce s rozšířenou působností Semily ${ }^{1}$
}

\author{
Markéta Zapletalová ${ }^{2}$ - Michal Soukop ${ }^{3}$ - Pavel Šaradín ${ }^{4}$ \\ Katedra politologie a evropských studií FF UP v Olomouci, Česká republika
}

The Practise of Participatory Budgets in the Czech Republic. A Case Study of the Municipality with Extended Power - Semily. The article focuses on participative budgeting; a case of a municipality with extended powers (ORP), particularly Semily, is investigated using the process-tracing method. This enables empirical observation of the causal mechanism in the period of implementation of participative budgeting (PB) and identification of the actual causes and conditions under which the mechanism functions. The investigation as proven that the municipality of Semily is a good example of a successful implementation and functioning of participative budgeting. The primary aim of the study is to fill the gap, at least partly, regarding the research into democratic innovations in the Czech Republic and participative budgeting in particular. The study is divided into three sections. The introduction presents the issue of participative budgeting and overviews the status quo in research. The first section clarifies the concepts and definitions related to participative budgeting in the context of democratic innovations. The second section explains case selection, data set and method of analysis, and the third section deals with a case study conducted with the municipality of Semily.

Sociológia 2020, Vol. 52 (No. 2: 180-200)

https://doi.org/10.31577/sociologia.2020.52.2.8

Key words: Participatory budgeting; Semily; local politics; democratic innovations

\section{Úvod}

Posilování účasti občanů na politice se stalo během posledních dvou dekád silným apelem, který rezonuje nejen oslabenými západními a postkomunistickými demokraciemi, jež čelí krizi důvěry v politiku a její elity. Zároveň přitahuje významnou odbornou pozornost. Gianpaolo Baiocchi a Ernesto Ganuza v knize Popular Democracy. The paradox of Participation (2016) si v této souvislosti vypůjčují slova bývalé ministryně zahraničí Hillary Clintonové a mluví o „věku participace“, podobně Caroline Lee, Michael McQuarrie a Edward Walker používají termín „participativní revoluce“ (Lee - McQuarrie, Walker in Baiocchi - Ganuza 2016: 2). Nárůst podpory občanské participace je dáván do souvislosti s krizí legitimity západních demokracií intenzifikované průběhem finanční krize a zvolenými způsoby jejího řešení, které zvýšily nedůvěru a

\footnotetext{
1 Článek vznikl v rámci výzkumného projektu GAČR (GA 17-20569S) „Demokratické inovace na lokální úrovni př́ípadová studie České republiky, Polska a Slovenska“.

2 Korespondence: Mgr. Markéta Zapletalová, Ph.D., Katedra politologie a evropských studií, Filozofická fakulta, Univerzita Palackého v Olomouci Kř́žkovského 12, 77180 Olomouc, Česká republika. E-mail: m.zapletalova@upol.cz

3 Korespondence: Mgr. Michal Soukop, Katedra politologie a evropských studií, Filozofická fakulta, Univerzita Palackého v Olomouci Krřržkovského 12, 77180 Olomouc, Česká republika. E-mail: michal.soukop@ upol.cz

4 Korespondence: Doc. Mgr. Pavel Šaradín, Ph.D., Katedra politologie a evropských studií, Filozofická fakulta, Univerzita Palackého v Olomouci Křrižkovského 12, 77180 Olomouc, Česká republika. E-mail: pavel.saradin@ upol.cz
} 
vyvolaly poptávku po změně. Od té se očekává zejména posílení role občanů prostřednictvím jejich účasti na rozhodnutích, jakožto i kontroly nad výkonem politiky a financemi (Röcke 2014: 9). Občanská participace je vnímána jako nástroj, který má akcentovat hlas těch, kteří jsou či se cítí být vyloučeni. Zároveň se přesunula z původní domény politické levice a aktivistů 60. - 70 . let do politického mainstreamu, kde je součástí navrhovaných řešení širokého spektra aktérů od ideologicky odlišně orientovaných politických stran, vlád, organizací a různých typů agentur (např. jedním z významných promotérů participativního rozpočtování, který zároveň vzbuzuje rozporné názory, je Světová banka ${ }^{5}$ ) až ke korporacím s evidentně rozdílnými zájmy i cíli. Původní klíčové koncepty sociální spravedlnosti spojované s konceptem radikální demokracie $\mathrm{v}$ rámci levicových př́stupů koexistují s instrumentálním pojetím organizací typu Světové banky plédujících za zkvalitnění vládnutí zvýšením transparence a efektivity (Baiocchi - Ganuza 2016: 3-5; Wampler et al. 2018: 6-7).

Participativní rozpočtování $(\mathrm{PB})$, při němž se občané podílejí na rozhodnutích ohledně využití veřejných peněz, můžeme označit za jádro současných participativních procesů, jejichž základem je posilování účasti občanů a které bývají souhrnně označovány jako demokratické inovace. Počátky praxe participativních rozpočtů jsou spojeny s koncem 80. let a rokem 1990, kdy byly vyzkoušeny ve 12 brazilských městech (Wampler 2007: 22), přičemž nejznámějším prŕípadem, kterému byla věnována zásadní odborná pozornost, se stalo město Porto Alegre. Porto Alegre se jako původní zdroj inspirace stalo modelem designu participativního rozpočtování označované jako spíše „otevřené, neformální a deliberativní“ a následné rozšiřování praxe směřovalo $\mathrm{k}$ větší formalizaci a precizaci postupů (Shah 2007: 6). Z brazilských měst se praxe z Porto Alegre přenesla např́ič Jižní Amerikou a nastoupila svou globální cestu ${ }^{6}$. Participativní rozpočty jsou dnes používány v mnoha zemích s odlišnou kulturou a politickými systémy (včetně těch nedemokratických) a liší se tak i cíle a očekávání s PB spjatá. Zatímco původní brazilský model z Porto Alegre je v kontextu křehké znovunastolené demokracie spojován zejména se snahou omezit korupci, patronát a sociální exkluzi, západoevropský kontext pak charakterizuje „demokratizace demokracie“, snaha o další posílení občanské společnosti nebo obecně efektivity výkonu správy (Wampler 2007: 23; Sintomer et al. 2013: 9).

V současné době participativní rozpočtování funguje či je ve fázi prípravy v celé řadě zemí na všech kontinentech, primárně na lokální úrovni, ve velkých městech pak obvykle na úrovni jednotlivých obvodů či městských částí. Řadí

\footnotetext{
5 Ke kontroverzně vnímané roli Světové banky v podpoře PB viz Goldfrank, Benjamin. 2012. The World Bank and the Globalization of Participatory Budgeting. Journal of Public Deliberation, vol. 8, issue 2, art. 7.

${ }^{6}$ Velká část autorů zároveň poukazuje na neobvyklý př́iběh objevu a transferu PB z globálního Jihu na globální Sever (např. Baiocchi, Ganuza 2016; Sintomer, Herzberg, Röcke 2013: 9, Röcke 2014: 2).
} 
se mezi ně zcela odlišná prostředí, jakými jsou velká západní města typu New Yorku, Paříže, Říma ${ }^{7}$, malé a střední obce až po sídla ve venkovských oblastech Keni či Indonésie. Počet měst a obcí v Evropě, kde je aplikován participativní rozpočet, trvale roste, a to i přes skutečnost, že po první vlně úspěšných projektů došlo $\mathrm{v}$ mnoha $\mathrm{z}$ nich $\mathrm{k}$ přerušení praxe. Př́kladem může být Itálie, kde $\mathrm{v}$ roce $2009 \mathrm{v}$ důsledku daňové reformy Berlusconiho vlády došlo ke zrušení většiny z okolo 150 fungujících participativních rozpočtů, podobně ve Španělsku v roce 2011, když většina lokálních vlád využívajících PB prohrála v lokálních volbách a nové vlády tuto praxi nepřevzaly. V prostředí střední a východní Evropy existuje zkušenost s participativními rozpočty např. na Slovensku, kde se Bratislava dokonce v roce 2011 stala tretím evropským hlavním městem, které zavedlo participativní rozpočet na celém území (Sintomer et al. 2013: 41, 43) ${ }^{8}$. Transparency International Slovensko ve své zprávě Otvorená samospráva 2018 sleduje 100 největších slovenských měst, přičemž participativní rozpočty má 17 z nich. (Piško 2018: 5). V Polsku se první PB odehrálo ve městě Sopoty v roce 2011 a v roce 2012 bylo v Polsku nejvíce př́ípadů PB z celé Evropy (Sintomer et al. 2013: 44), v roce 2014 již bylo PB praktikováno v cca 80 městech včetně hlavního města Varšavy. Zákon z ledna 2018 následně nastavil regulatorní pravidla a také zpřísnil podmínky pro lokální vlády tak, aby respektovaly rozhodnutí učiněná občany v procesu PB (Kębłowski - van Criekingenb 2014: 369; Bednarska-Olejnicsak - Olejnicsak 2018: 341). Česká republika má zkušenosti s participativními rozpočty od roku 2012, od té doby byla praxe vyzkoušena v 38 městech, přičemž očekávání pro rok 2019 počítají s nárůstem až na 53 př́ipadů (Agora Central Europe 2018). V kontextu zemí Visegrádské čtyřky se vymyká Mad’arsko, kde dosud nebyl žádný projekt participativního rozpočtování realizován (Sipos - Reszkető 2019).

Fenomén rychlé difuze PB je objasňován jeho „úspěšným př́iběhem“a pozitivními očekáváními ohledně sociální transformace na vícero úrovních. Naděje zastánců shrnují Walper, McNulty a Touchton (2018: 4) do dvou hlavních bodů. Zaprvé, změny v chování a přistupech jednotlivců, kteří se procesu účastní, tedy občanů, politiků i úředníků, zároveň se očekává, že se zvýší podpora procesů demokratické tvorby politiky, posílí se sociální důvěra a demokratická legitimita. Zadruhé, procesy participativního rozpočtování mají

\footnotetext{
${ }^{7}$ V Římě mají zkušenost s participativními rozpočty v některých městských částech, v červnu 2019 pak, poprvé v historii, vedení města $\mathrm{v}$ čele se starostkou Virginií Raggi z Hnutí 5 Hvězd zahájilo proces participativního rozpočtu na celém jeho území. V procesu se bude rozhodovat o využití celkové částky 20 milionů eur, které jsou určeny ke zkrášlení městského prostředí a zelených ploch. Finální online hlasování o projektech je plánováno na říjen 2019 (Roma Capitale 2019). Prvním evropským hlavním městem, které zavedlo celoměstský participativní rozpočet, byl Lisabon v roce 2008. Podrobněji viz (Allegretti - Antunes 2014).

8 Bratislavský experiment však netrval dlouho a po několika letech byl ukončen (Klimovský 2017: 16). K tomu také Hrabinová (2018, nestránkováno) uvádí, že PB zanikl v roce 2014, a to kvůli nerealizování některých projektů. Dnes však opět funkční je.
} 
spustit efekt spill-overu, který bude znamenat zlepšení ve čtyřech hlavních oblastech vymezených následovně: a) silnější občanská společnost (zvýšením počtu a aktivit organizací a jejich napojením na vládní struktury); b) posílení transparentnosti; c) zvýšení odpovědnosti (zapojení občanů zvyšuje jejich informovanost a vládní úroveň více odpovídá na jejich požadavky); d) zlepšení sociálních výstupů (zejména v souvislosti s větší responsivitou vlád ve vztahu k občanům a znevýhodněným komunitám). Zkoumání, nakolik jsou tato očekávání naplňována v souvislosti jak s kvalitou demokracie, tak sociální změnami, a jaké jsou výsledky a dopady PB, pak tvoří významnou linii stávajícího výzkumu.

Jak upozorňuje Anwar Shah (2007), PB má rovněž svá úskalí, která mohou mít velmi negativní efekt na očekávané výstupy. Tato situace nastane napřr. v momentě, kdy je proces ovládnut zájmovými skupinami. Fasáda inklusivní participace a vládnutí pak skrývá nedemokratické praktiky řízené elitami a/nebo ekonomickými zájmy, v důsledku čehož může docházet $\mathrm{k}$ posilování sociální nerovnosti, dalšímu vyloučení marginalizovaných či exkludovaných skupin a posilovaní nelegitimního výkonu moci. Může být spouštěčem „tyranie rozhodování a kontroly“, kdy jsou obcházeny legitimní rozhodovací procesy, „tyranie dynamiky skupiny“, jež upevňuje pozice a zájmy vládnoucích elit, nebo „tyranie metod“, která umožní vyloučit jiné, v daném kontextu vhodnější (tj. obecně více demokratické) metody. Aby bylo zajištěno, že $\mathrm{k}$ těmto situacím nebude docházet, „participativní procesy musí plně respektovat lokální politiku, formální i neformální mocenské vztahy, tak aby tyto generovaly výstupy prospěšné pro běžného občana (median voter)“(Shah 2007: 1-2).

Vzhledem $\mathrm{k}$ historii a rozšíření demokratických inovací a participativních procesů není překvapivé, že vědecký korpus věnovaný této problematice je již velmi obsáhlý. Jedná se o výrazně dynamicky se rozvíjející oblast výzkumu, kterou ovšem komplikuje skutečnost, že zkoumané procesy a procedury jsou v permanentním vývoji. To znesnadňuje zejména uplatnění rozsáhleji pojatých koherentních komparativních př́istupů (large- $N$ studies) využívajících statistické analýzy, které v rámci výzkumu demokratických inovací představují nejnovější generaci a nutně pracují s množstvím dat, jež však rychle zastarávají. Zároveň narážejí na nekompatibilitu údajů v souvislosti s velkými odlišnostmi v pojetích, disciplinárních prístupech, metodologii a cílech uplatňovaných $\mathrm{v}$ jednotlivých př́padových studiích první generace a $\mathrm{v}$ následujících srovnávacích studiích pracujících s několika př́pady (small-N studies) (Walper et al. 2018: 7-8; Sintomer et al. 2016: 6-7). V zásadě lze uvažovat o několika vlnách zájmu o participativní rozpočtování, které reflektuje odborná literatura. Reflexe začíná př́padem brazilského města Porto Alegre (Abers 1998; Santos 1998), jak jsme uvedli výše, pokračuje k dalším př́ípadům ,jihu“ a komparativním studiím (Dias 2014; Hernández-Medina 2007; Raza - Thébault 2006; Avritzer 
2002; Heller 2001). Další vlna zkoumá pronikání a etablování této demokratické inovace do zemí západního světa, který se potýká s nárůstem občanské apatie a snižující se volební účastí (Röcke 2014; Pinnington et al. 2009; Gret Sintomer 2005). Následuje pak implementace participativního rozpočtování v postkomunistických zemích (Wisniewska 2018; Klimovský 2017; Vojtíšková 2016; Krenjova - Raudla 2013).

Zatímco $\mathrm{v}$ př́ípadě Polska můžeme hovořit o poměrně rychle se rozvíjejícím výzkumu, kde studie reflektují jednotlivé prrípady a tyto jsou rovněž součástí šíreji zaměřených výzkumných projektů, co se týká stavu výzkumu participativního rozpočtování v České republice, situace je zcela neuspokojivá. Až na výjimky (např. Hurtíková - Soukop 2019; Motyčková 2018; Šmerdová 2016; Vojtíšková 2016; Vítková 2014) nejsou k dispozici ucelené studie, jež by se s využitím koherentních metodologických prístupů zabývaly zaváděním demokratických inovací, v prrípadě PB dosud nebyly hlouběji analyzovány ani jednotlivé př́pady. K dispozici jsou spíše studie a literatura, jež problematiku zachycuje parciálně obvykle v souvislosti s tématy fungování lokální politiky či její reformou, přičemž převažují texty, které se vztahují k obecním referendům (Burešová - Balík 2019; Lažová 2017; Smith 2009; Čermák - Stachová 2007; Smith 2006), či např. studie vypracované neziskovou organizací Agora Central Europe, věnující se mj. právě podpoře zavádění a také základnímu monitoringu PB v ČR (viz např́klad web https://www.participativni-rozpocet.cz/). Důvody lze hledat ve skutečnosti, že Polsko můžeme zařadit k zemím s vysokou dynamikou zavádění a rozvoje $\mathrm{PB}$, kdežto situace $\mathrm{v} \breve{C} \mathrm{R}$ je odlišná z hlediska kvantitativního, rovněž téma demokratických inovací není v ČR dlouhodobě součástí politického diskurzu na žádné z úrovní vlády.

Smyslem předkládané studie je alespoň částečně zaplnit tuto zásadní mezeru ve výzkumu. Vzhledem $\mathrm{k}$ výše popsané absenci základních studií, zejména jednopř́ípadových (case-based), které by poskytly výchozí údaje o formátech, metodách, aktérech či procedurálních modelech, naše zaměření zůstává ve svých ambicích poměrně omezené. $V$ rámci našeho projektu jsme se soustředili v letech 2017 - 2019 na sběr dat v obcích s rozšířenou pưsobností $(\mathrm{N}=205)$, přičemž jsme zaznamenali rychlou difuzí participativní praxe na území ČR. Nicméně ke skutečnému prosazovaní $\mathrm{PB}$ dochází až po lokálních volbách 2018, tento krátký časový úsek však neumožňuje dostatečně zohlednit úspěšnost zavádění $P B$. Proto jsme se zaměřili na jednopř́padovou studii města Semily, kde jsme testovali kauzální mechanismus implementace nástroje participativního rozpočtování na základě metody process-tracing dle metodologie Beache a Pedersena (2019). 


\section{Participativní rozpočty v rámci konceptu demokratických inovací}

Participativní rozpočty jsou součástí širšího pole zájmu spojeného se zkoumáním participativních nástrojů, tj. oblasti demokratických inovací, které jsou nejčastěji umíst'ovány do rámců teorií participativní a deliberativní demokracie (Sintomer et al. 2008: 165). Samotné definiční vymezení demokratických inovací není v akademickém prostředí reflektováno jednotně. Např. Kenneth Newton vymezuje demokratické inovace jako ,úspěšnou implementaci nových myšlenek, které mají změnit struktury nebo procesy demokratické vlády nebo politiky s cílem je zlepšit“, vágní termín „inovace“ pak odděluje od pouhých reforem jakožto „více radikální změnu implikující diskontinuitu nebo kvalitativní rozchod s do té doby existujícím stavem věcí “ (Newton 2012: 4-5). Brigitte Geissel poukazuje na skutečnost, že zavádění demokratických (participačních) inovací zpravidla neznamená objev nové praxe, ale jedná se o novou aplikaci či nápodobu procesů již existujících či fungujících $v$ jiných kontextech. To, co můžeme nazvat demokratickou inovací v jedné zemi či kontextu, může být fungující praxí v jiné zemi či kontextu. Proto demokratické inovace definuje jako „nové praktiky, jež jsou zavedeny záměrně a smysluplně s cílem zlepšit kvalitu demokracie bez ohledu na to, zda daná inovace již byla vyzkoušena v jiném systému“ (Geissel 2009: 53). Baiocchi a Ganuza ztotožňují demokratické inovace s „novými participativními nástroji“, které „otevírají nový politický kontext s významnými dopady na výkon demokracie“ (Baiocchi - Ganuza 2016: 15). Demokratické inovace „cestují, jsou replikovány, kopírovány a jednoduše adaptovány ve výrazně odlišných kontextech“ (Baiocchi Ganuza 2016: 18), zároveň mohou být zaváděny na různých systémových úrovních, at' již lokální, národní či dokonce nadnárodní. Lokální úroveň však můžeme považovat za prostředí, které se pro generování demokratických inovací stalo zásadním a odkud dochází $\mathrm{k}$ difuzi horizontální, tj. napříč systémy do jiných lokálních kontextů, tak rovněž vertikální, tedy na další systémové úrovně.

Vzhledem k problematickému terminologickému pozadí spojení „demokratické inovace" však vyvstává komplikace s určením konkrétních praktik, procesů a postupů, jež mohou být jako demokratické inovace identifikovány. Geissel na základě předchozí analýzy existující literatury uvádí čtyři hlavní demokratické inovace: 1) př́má demokracie, kdy je hlasováním občanům umožněno podílet se na rozhodnutí či vyjádřiit svůj názor (např́íklad prostřednictvím referend či návrhů legislativních aktů); 2) co-governance, umožňuje sdílení rozhodovací pravomoci s dalšími politickými aktéry z řad občanů, občanské společnosti nebo zástupci zájmových skupin (sem je možné zařadit napr. participativní rozpočtování či plánování); 3) konzultativně-diskurzivní procedury, při nichž dochází k participaci prostřednictvím diskuse, ovšem vliv 
na rozhodování je determinovaný vưlí politické reprezentace se výsledky řídit; 4) volební reformy ( $\mathrm{tj}$. způsob volby politické reprezentace, např. posílení personalizace úřadu prostřednictvím přímé volby starosty) (Geissel 2009: 53). K nejsilnějšímu projevu pravomocí občanů dochází v prvním typu inovací, kdy rozhodují sami.

Jedná se stále o poměrně široce definované okruhy způsobů participace, které umožňují velkou variabilitu v určování a zařazování jednotlivých demokratických inovací. Na tuto situaci nedávno reagovali autoři Stephen Elstub a Oliver Escobar (2017), kteří prostřednictvím nové revize existujících definic nabízejí vlastní vymezení demokratických inovací a zároveň jejich přehlednou typologii. Demokratické inovace Elstub a Escobar definují jako „procesy nebo instituce vyvinuté k novému pojetí a prohloubení role občanů v procesech vládnutí zvýšením př́ležitostí k participaci, deliberaci a vlivu“ (Elstub Escobar 2017: 14). Při nastavování analytické typologie vzali autoři v úvahu jednotlivé aspekty, které se v různých pojetích a explanacích demokratických inovací objevovaly $\mathrm{s}$ odlišnou intenzitou (či absentovaly). Výsledkem je komplexní náhled, jenž kombinuje „kvazi-kontingentní znaky“, odkazující na institucionální možnosti participace, a „kontextuální podmínky“, které se vztahují ke kontextu, v němž je demokratická inovace aplikována. Kvazikontingentní znaky zahrnují metody výběru účastníků (ty se mohou pohybovat na škále exkluzivní - inkluzivní), dále pak způsoby participace, způsoby rozhodování a rozsah moci a vlivu, přičemž posledně tři jmenované se mohou lišit mírou intenzity (např. v př́padě způsobu účasti je pouhá př́tomnost účastníka-občana jako pozorovatele daleko méně intenzivní než jeho zapojení v případě hlasování nebo prostřednictvím diskurzivního př́stupu). Kontextuální podmínky následně vymezují možnosti nabízené kvazi-kontingentními znaky konkrétní demokratické inovace a zahrnují úroveň vládnutí (level of governance), fázi (policy stage) a oblast politiky (policy area) (Elstub - Escobar 2017: 15-21). Na základě průniku definičních vlastností demokratických inovací a analytického nastavení kvazi-kontingentních znaků a kontextuálních podmínek autoři vymezují pět „rodin demokratických inovací“. 1. mini-publics; 2. participativní rozpočet; 3. referenda a občanské iniciativy; 4. kolaborativní vládnutí (collaborative governance); 5. digitální participace (Elstub Escobar 2017: 22-25). Tyto rodiny demokratických inovací vykazují společné znaky, avšak zároveň vysokou míru variability v rámci vymezených kvazikontingentních a kontextuálních znaků, rovněž mohou vznikat hybridní kombinace demokratických inovací (Elstub - Escobar 2017: 25).

Participativní rozpočet je zde tedy vymezen jako samostatná rodina $\mathrm{v}$ rámci demokratických inovací. Z pohledu kontextuálních rysů se jedná o demokratic- 
kou inovaci vzešlou a spojenou primárně s lokální úrovní ${ }^{9}$. Co se týká jednotlivých kvazi-kontingentních rysů, prvním jsou metody výběru účastníků. Ty mají v případě participativního rozpočtu velmi inkluzivní charakter a možnost účastnit se je obvykle otevřena všem občanům dané územní jednotky (self selection). Dle Elstuba a Escobara však mohou zahrnovat i volbu, kdy občané zvolí své delegáty, kteří následně na procesu participují, a účelovou selekci (purposive selection) účastníků, kdy jsou občané vyzváni k účasti (vybráni) z důvodu svých znalostí, zájmů, či protože zastupují různé zájmy nebo komunity (Elstub - Escobar 2017: 16, 23). Způsoby participace variují od v zásadě obvyklého hlasování (více intenzivní), jímž jsou rozhodnutí činěna, přes diskurzivní vyjádření (discursive expression) (intenzivní) až k pouhým náslechům (listening) (Elstub - Escobar 2017: 17, 23). Důležitým momentem je následný způsob, jakým je činěno rozhodnutí. Otázka je, do jaké míry mohou občané ovlivnit konání veřejného aktéra-tvưrce politiky: zda občané vykonávají př́mou autoritu (přímo rozhodují), př́ípadně se stávají partnery v rámci sdílené autority (co-governance) (Elstub - Escobar 2017: 19, 23).

Jak je patrné i z obrysů Elstubova a Escobarova konceptu, procesy participativního rozpočtování jsou charakteristické nesmírně širokou škálou svého nastavení a nelze tak určit jeden konkrétní model. Je to dáno v prvé řadě skutečností, že se jedná o jednu z nejrozšířenějších demokratických inovací, jejíž fungování dnes můžeme sledovat na př́padech $\mathrm{z}$ různých regionů $\mathrm{v}$ podstatě $\mathrm{v}$ globálním měřítku, přičemž procesy difuze s sebou nesou redefinici jak ideových rámců, tak prrizpůsobení metod, dochází tedy $\mathrm{k}$ jejich celkové hybridizaci. Zatímco základní zásady a institucionální předpoklady bývají shodně naplněny, jednotlivé procesy pak reflektují kontextuální odlišnosti a zvláštní podmínky (politické, sociální aj.) každého obvodu nebo města (Wampler 2007: 22-23). To nás přivádí k problému samotné definice participativního rozpočtu. Skutečností je, že neexistují žádná daná vymezení, obecně akceptovaná kritéria, která musí být splněna. Často je participativní rozpočet definován jako proces, v němž (nevolení) občané rozhodují o rozdělení (části) veřejných prostředků. Tak obecná identifikace však může vést $\mathrm{k}$ zaměňování $\mathrm{PB} \mathrm{s}$ nápodobnými formami, což jistě znamená problém pro jakékoliv snahy o komparativní výzkum. V praxi pak mohou představitelé lokálních vlád prezentovat své (zcela neparticipativní) postupy jako $\mathrm{PB}$, je to součást jejich rétoriky a proklamací, protože jsou si vědomi, že se jedná o žádoucí praxi, čímž vylepšují vlastní obraz. Za PB jsou pak třeba vydávány různé nezávazné (obvyklé) konzultace s představiteli jednotlivých městských částí, nebo zvláštní dotace městským částem, kdy si jejich komise mohou určovat, co se za ně pořídí ${ }^{10}$.

9 Mohou existovat i výjimky zahrnující meso-level, například k PB se uchýlil Trnavský kraj, tedy regionální samosprávný stupeň.

${ }^{10}$ Na takové případy narazili autoři při sběru dat a tvorbě databáze pro projekt, jehož součástí je i tato studie. 
Potřeba preciznější definice pro komparativní výzkum vedl autory Sintomera et al. (2008: 168) k nastavení pěti kritérií, která napomáhají definici PB: 1. musí se jednat o finanční nebo/a rozpočtové záležitosti; 2. musí zahrnovat městskou úroveň nebo úroveň městských částí, které mají volené úřady a administrativní pravomoci; 3. má se jednat o proces, který je opakovaný (pokud proběhne jedno setkání nebo jedno referendum o finančních otázkách, o participativní rozpočet se nejedná); 4. BP musí zahrnovat nějakou formu veřejné deliberace $\mathrm{v}$ rámci specifických mítinků nebo fór (nejedná se o pouhé přizvání občanů k obvyklým jednáním v rámci administrativních nebo politických postupů); 5. kritérium obsahuje požadavek, aby zde existovala jistá odpovědnost ve vztahu $\mathrm{k}$ výstupu procesu. Jak vyplývá $\mathrm{z}$ výše uvedeného, konkrétní pravidla a administrativní metody a postupy, které jsou uplatňovány v procesech $\mathrm{PB}$, se významně liší. Jejich podobu ovlivňují kontextuální podmínky, rozhodující je velikost obce (a tím i rozpočtu), sociální, ekonomické, politické a další. Dnes hraje podstatnou roli, nakolik jsou v procesu PB využívány digitální technologie a sociální sítě, které velmi usnadňují komunikaci a samotné hlasování.

\section{Data, volba př́padu a metoda analýzy}

Základní sledovanou jednotkou v našem výzkumu jsou obce s rozšířenou působností (ORP). Z hlediska rozsahu samostatné působnosti platí, že je pro všechny obce stejný, nicméně z hlediska povinností, které zabezpečují v rámci přenesené působnosti, se jednotlivé obce liší. Zákonodárce $\mathrm{v}$ zákoně o obcích č. 128/2000 Sb. stanovil rozdělení na obce, které vykonávají přenesenou působnost $\mathrm{v}$ základním rozsahu, na obce $\mathrm{s}$ pověřeným obecním úřadem a dále na obce s rozšîřenou působností. ORP mají zákony svěřené další úkoly státní správy, které nevykonávají pouze na svém vlastním území, ale rovněž pro všechny obce ve svém správním obvodu. Počet ORP činí 205. Ačkoliv se v př́ípadě ORP jedná o administrativní členění země a ORP je uměle vytvořenou entitou, objevují se pokusy jak v praktické i teoretické rovině jejich existence využít. V prvním př́ipadě Svaz měst a obcí ČR počítal s ORP jako centry meziobecní spolupráce, na které chtěl delegovat další pravomoci, ve druhém př́padě jsou používány ve výzkumu, a to nejen $\mathrm{v}$ oblasti veřejné správy, ale rovněž politologie (Balík 2008). Z podobného důvodu jsme si ORP ve svém výzkumu zvolili také my. Těchto 205 obcí je dostatečný počet jednotek, abychom je mohli zkoumat $\mathrm{s}$ očekáváním relevantních závěrů ohledně zavádění a působení demokratických inovací, v tomto př́padě participativních rozpočtů.

V našem výzkumu jsme sestavili korpus, ve kterém jsme sledovali přibližně 20 politických proměnných a př́tomnost demokratických inovací, a to u všech ORP. Jednalo se například o výsledky voleb, výši volební účasti, složení rady, 
politickou př́slušnost starosty/starostky, počet uskutečněných místních referend, způsob komunikace vedení obce atd. Mezi nimi jsme sledovali rovněž to, zda př́śslušná ORP používá metodu participativního rozpočtování. Zaměřili jsme se na léta 2016, 2017, 2018 a 2019. Pro sestavení databáze o participativních rozpočtech jsme vycházeli z dat, která nám poskytli představitelé ORP. Ta jsme následně ověřovali prostřednictvím webových stránek obcí, případně telefonátů a také $\mathrm{z}$ různých veřejných zdrojů. Jistým problémem, jak se ukázalo, je samotný pojem participativní rozpočet. Představitelé obcí, jak jsme naznačili výše, $\mathrm{k}$ němu přistupovali poměrně benevolentně a rozhodně se v některých př́ípadech nemuselo jednat o propracovaný nástroj, který využívá zapojení občanù ${ }^{11}$. Další ověření a potvrzení informací pocházejících od zástupců ORP bylo tedy nezbytným krokem. Podle našich zjištění $\mathrm{PB}$ používalo $\mathrm{v}$ roce 2017 10, v roce 2018, stejně jako v roce 201931 obcí s rozšsiřrenou působností. Během ověřování těchto údajů jsme zjistili, že naprostá většina těchto obcí zavádí rozpočet prostřednictvím iniciativy Národní sít' zdravých měst (NSZM), př́padně nějaké neziskové organizace.

Vzhledem k výše popsané absenci praxe PB v ČR jsme se nemohli soustředit na nejpodstatnější krok, tj. na vyhodnocování úspěšnosti těchto rozpočtů, ani na jejich celkové zhodnocení ${ }^{12}$. Z tohoto důvodu jsme se v této studii zaměřili na samotný proces implementace nástroje participativního rozpočtování ve vybrané obci - Semily ${ }^{13}$. Př́i empirickém testování vycházíme z metodologie tzv. mechanism-based př́stupu (také case-based prístupu), konkrétně metody process-tracing definované Beachem a Pedersenem (2019; obecně k metodě process-tracing viz také Beach - Pedersen 2018; Bennett - Checkel 2014; Mazák 2017), která umožňuje empirické testování jednotlivých částí předpokládaného kauzálního mechanismu za současné kontroly potenciálních alternativních vysvětlení na úrovni empirické evidence ${ }^{14}$. Metoda process-tracing nesleduje př̀edpokládaný efekt př́činy na důsledek $(\mathrm{X} \rightarrow \mathrm{Y})$, který zjištuje např. regresní modelování či jiné statistické techniky, ale podrobně sleduje pouze mechanismus, který přričinu a důsledek spojuje (za podmínky, že příčina a důsledek jsou v testovaném př́ípadu prítomny - viz typický př́pad níže),

\footnotetext{
11 Př́kladem může být Olomouc. Doposud (2019) ve městě neexistuje standardní $\mathrm{PB}$, nicméně vedení města dlouhodobě poskytuje městským částem (nemají ale vlastní samosprávu) částku zhruba 300 tisíc korun na nejrůznější opravy, údržbu chodníků, výsadbu zeleně a další drobnou činnost. $\mathrm{O}$ využití této částky rozhoduje komise městské části, přičemž suma neni poukázána přímou platbou. Doporučí-li komise opravu chodníku, ta je provedena Technickými službami města Olomouce (príspěvková organizace).

12 Datový korpus umožňuje srovnání zavedení demokratických inovací, vliv politické př́slušnosti či složení koalice na prosazování těchto nástrojů, což však není předmětem této studie.

13 Obec se zhruba 8400 obyvateli ležící v Libereckém kraji, která pracuje z pozice ORP pro dalších 22 obcí.

14 Potvrzení funkčnosti konstruovaného kauzálního mechanismu neznamená, že neexistují platná a podložitelná alternativní vysvětlení vztahu mezi danou př́činou a následkem. Metoda process-tracing sleduje a empiricky testuje právě jeden potenciálně možný kauzální mechanismus, aniž by cokoliv říkala o jiných existujících mechanismech (k problematice viz Beach - Pedersen 2019).
} 
definuje očekávaná pozorování a jednotlivé kroky mechanismu dokládá empirickou evidencí. Námi konstruovaný kauzální mechanismus je tzv. theorytesting minimal process-tracing design, který stanovuje jen stěžejní kroky mechanismu a jejich základní propojení bez ambice přesně popsat a doložit veškeré dílčí mezikroky celého procesu. S ohledem na snahu o zobecňování na tzv. typické prrípady by konstrukce úplného kauzálního mechanismu dle metodologie Beache a Pedersena (2019) nebyla ani žádoucí.

Obec Semily byla pro testování zvolena ze trrí důvodů. Za prvé, Semily dle definice Sintomera et al. (2008: 168) prokazatelně využívají participativní rozpočet ${ }^{15}$. Zároveň z pohledu Elstubovy a Escobarovy typologie daný proces s ohledem na kvazi-kontingentní rysy vykazuje velmi inkluzivní a intenzivní charakter, co se týká metody výběru účastníkủ (self selection, podpořený navíc posunem obvyklé věkové hranice - viz níže) a způsobu participace. Vzhledem ke způsobu, jakým je činěno rozhodnutí, můžeme navíc ve zvoleném př́padě hovořit o výkonu př́mé autority občany. Za druhé, Semily naplňují podmínky tzv. typického prípadu (př́ípad, kde je prítomna jak předpokládaná př́íčina, tak důsledek - zavedení PB do obecní praxe - a očekává se působení definovaného kauzálního mechanismu) dle stanovené metodologie mechanism-based př́stupu (viz Beach - Pedersen 2018, 2019). Stanovení př́ičiny testovaného kauzálního mechanismu nabízelo dvě možnosti. Bud' zvolení předpokladu efektu exogenních faktorů, kdy by $\mathrm{k}$ implementaci inovativních nástrojů docházelo vlivem působení externích aktérů (např. tlak neziskových organizací, nařízení Vlády ČR apod.), anebo zvolení předpokladu efektu endogenních faktorů, kdy impulz $\mathrm{k}$ implementaci nástrojů pochází $\mathrm{z}$ vnitřního rozhodnutí některé politické strany působící v zastupitelských tělesech dané obce. Jelikož Semily nejsou např. členy NSZM, která př́mo podporuje zavádění inovativních nástrojů na lokální úrovni v rámci MA21, nemáme informace o tlaku jiných externích aktérů ani v kontextu Č́R zpravidla nedochází $\mathrm{k}$ nařízení implementace inovativních nástrojů z národní úrovně, zvolili jsme jako př́činu endogenní efekty v podobě rozhodnutí prosadit implementaci PB do obecní praxe v jedné z politických stran působících $\mathrm{v}$ dané obci. Bude-li náš testovaný kauzální mechanismus empiricky potvrzen, lze říci, že obdobný mechanismus splňující kontextuální podmínky může působit ve všech obcích spadajících do kategorie typických případů. Nelze však vyloučit existenci alternativních mechanismů naplňujících jev ekvifinality. K odhalení dalších potenciálně existujících mechanismů by bylo nutné analyzovat více než jeden př́ípad. A za třetí, Semily vykazují v datovém souboru ORP vysokou míru využívání nástrojů demokratických inovací

\footnotetext{
${ }^{15} \mathrm{Z}$ jistého pohledu by se mohlo zdát, že participativní rozpočet neprovází deliberace $\mathrm{v}$ rámci nějakého specifického fóra (viz tabulka 1). Toto kritérium však př́tomno je, protože hlasování považujeme za nejsilnější formu deliberace. Vytváření specifických fór v malém městě nemusí být potřebné, vzhledem $\mathrm{k}$ tomu že lidé se velmi často potkávají, jsou v osobním kontaktu s vedením města, účastní se nejrůznějších veřejných slyšení atd.
} 
dle standardizovaného indexu DI. Pokud předpokládáme existenci synergického efektu při využívání inovativních nástrojů, vysoká míra využití těchto nástrojů podpoří implementaci $\mathrm{PB} \mathrm{z}$ rozhodnutí jedné ze stran $\mathrm{v}$ rámci obce. Navrhovaný kauzální mechanismus prezentuje schéma č. 1.

Schéma č. 1: Navrhovaný kauzální mechanismus procesu implementace PB do obecní praxe

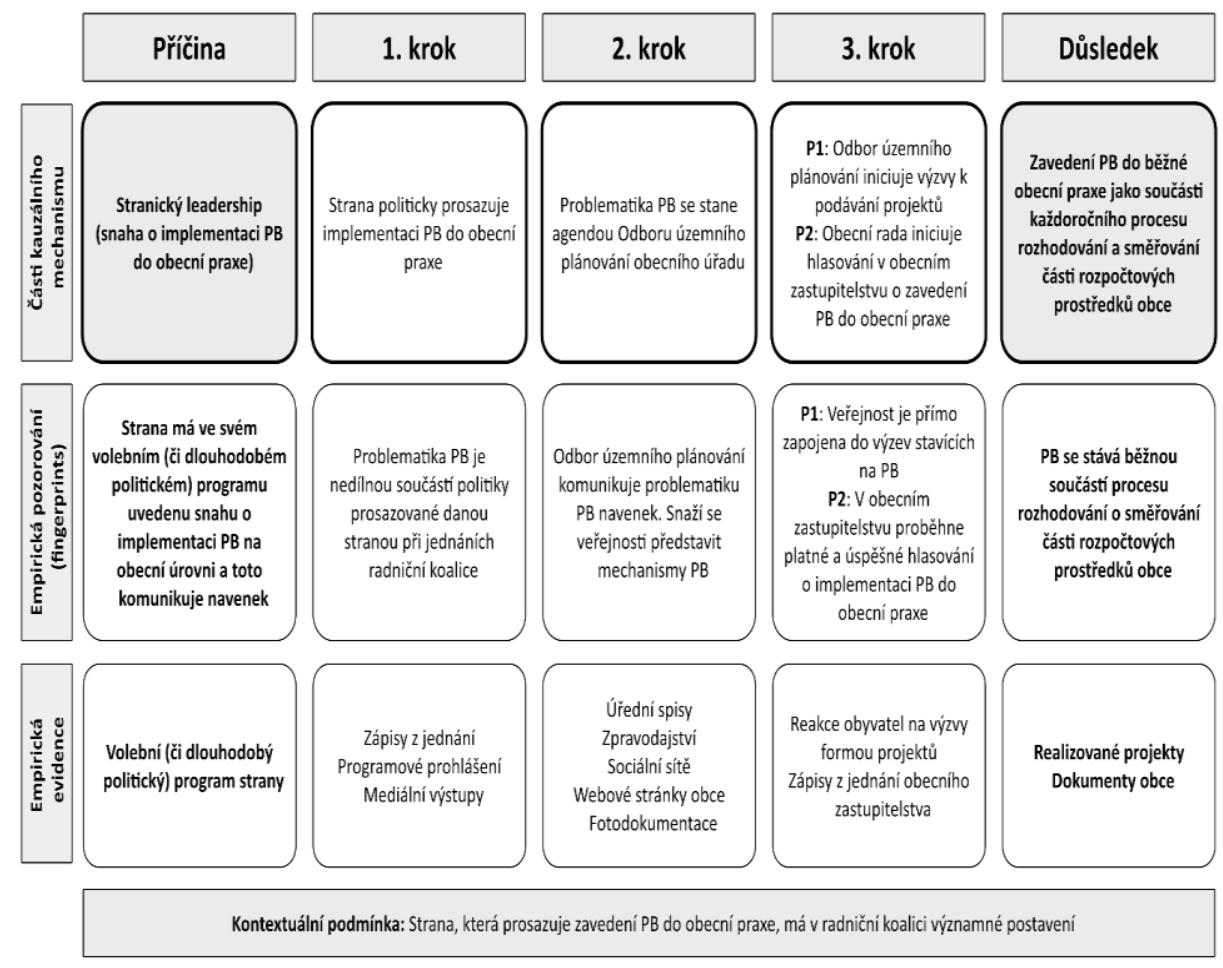

Pozn.: Kauzální mechanismus konstruován dle metodologie Beache a Pedersena (2019); Schéma je ilustrativní, v Semilech (krok 3) rozhoduje a technicky na projekt dohlíží Odbor rozvoje a správy majetku.

Stanovenou prŕčinou je tzv. stranický leadership. Strana, která splňuje kontextuální podmínku umožňující spuštění kauzálního mechanismu (strana má $\mathrm{v}$ radniční koalici významné postavení, tedy se $\mathrm{v}$ rámci koalice nejedná o stranu marginální), ve svém volebním či dlouhodobém politickém programu prosazuje zavedení participativního rozpočtování do obecní praxe. Tato snaha je komunikována bud' při programových jednáních radniční koalice, nebo je př́mo politicky prosazována danou stranou (1. krok kauzálního mechanismu). Úspěšnost snahy politické strany o zavedení PB do obecní praxe dokládá impulz k převedení problematiky do agendy Odboru územního plánování dané 
obce, který problematiku PB komunikuje navenek a snaží se o představení základních funkčních mechanismů PB směrem $\mathrm{k}$ veřejnosti (2. krok kauzálního mechanismu).

Počátek komunikace mechanismů $\mathrm{PB}$ směrem $\mathrm{k}$ veřejnosti se rozvíjí $\mathrm{v}$ podobě iniciace výzev $\mathrm{k}$ podávání projektů ze strany veřejnosti $\mathrm{k}$ realizaci $\mathrm{v}$ rámci participativního rozpočtování. Tento první dílčí krok další části kauzálního mechanismu by se měl opakovat až do překročení minimálního prahu nabytých zkušeností, na základě kterých Obecní rada iniciuje hlasování v obecním zastupitelstvu o zavedení PB do obecní praxe (3. krok kauzálního mechanismu), jehož výsledkem je samotná implementace mechanismu PB do běžného rozhodovacího procesu na obecní úrovni jako důsledku celého mechanismu.

\section{Př́́padová studie Semily - empirické doložení př́ípadu dle metody process- tracing}

Snaha o zavedení participativního rozpočtu do obecní praxe započala $\mathrm{v}$ roce 2015 na popud vítěze voleb, kterým byla Volba pro Semily (zisk 35 procent hlasů). Evidenci procesu obsahuje tabulka č. 1, kde jsou uvedeny odkazy na jednotlivé kroky a kvůli názornosti i krátký popis, citace či titulek z uvedeného periodika. Hnutí jej mělo jako jednu z priorit ve svém volebním programu pro komunální volby roku 2014 (1a). Jeho realizace byla ovšem opožděna, především kvůli povolebním jednáním, kdy vznikla koalice bez vítěze voleb, a to ve složení hnutí ANO (17 procent) společně s ČSSD, Semiláky spolu s KDU-ČSL a hnutím SPOLU ${ }^{16}$. Jelikož žádný z těchto subjektů neměl ve volebním programu participativní rozpočet, neobjevil se tak přrirozeně ani v programovém prohlášení. Změna situace nastala po jednání zastupitelstva 25. 3. 2015, kde byla starostka Věra Blažková (hnutí ANO) odvolána kvůli nezvládnutí problémů v nemocnici v Semilech. Ještě téhož dne pak zastupitelstvo zvolilo do čela města Lenu Mlejnkovou (Volba pro Semily) a do rady se dostali zastupitelé hnutí Volba pro Semily. Nově vzniklá koalice již své programové prohlášení nevytvořila, což nová starostka zdůvodnila zejména tím, že její hnutí kandidovalo s konkrétním programem, který chce plnit. Jak dále dodala, na konci volebního období pak skládá voličům a obyvatelům města účty a hodnotí, co vše z volebního programu splnila ${ }^{17}$. V souladu s programem hnutí (2a) tak byl představen návrh participativního rozpočtu nově zvoleným místostarostou Tomášem Sáblem (Volba pro Semily) na jednání zastupitelstva 20. 4. 2015 (zmíněn již 25. 3., ovšem zde byl stažen z projednávání v zastupitelstvu) (4a,

\footnotetext{
16 https://www.idnes.cz/liberec/zpravy/koalice-dohoda-jednani-geotermalni-elektrarna-ano-cssd-kdu-csl.A141024_084 609_liberec-zpravy_ddt

17 Telefonický rozhovor se starostkou Semil. (5. 12. 2019)
} 
$4 \mathrm{~b}, 4 \mathrm{c})$. Na tomto jednání byl schválen objem financování pro participativní rozpočtování (1 mil. korun), podrobný harmonogram i způsob a rozsah informování. Tento návrh se od participativních rozpočtů ostatních měst značně lišil především bodem, který umožňoval participaci občanů již od 16 let (4d). V naprosté většině př́padů mohou totiž hlasovat pouze obyvatelé, kteří dosáhnou plnoletosti. Příčina a první krok definovaného kauzálního mechanismu tak byly formálně naplněny a doloženy. Kauzální mechanismus byl v př́ípadě Semil spuštěn splněnou kontextuální podmínkou, kdy hnutí Volba pro Semily stálo v pozici dominantní politické síly v obci.

Druhý krok kauzálního mechanismu koresponduje s reálným procesem, kdy technicky prováděl př́ípravu PB Odbor rozvoje a správy majetku MěÚ Semily (3a). Pro projekt participativního rozpočtu bylo vytvořeno oficiální logo a plakáty, pomocí nichž byl prezentován veřejnosti. Doprovázel jej slogan Investice na přání, který byl zároveň inspirací pro název samostatného webu města vyhrazeného pouze pro participativní rozpočet. První informace o projektu byly zveřejněny po dubnovém jednání zastupitelstva, pak vždy po důležitých krocích, jakými byly: výzva k podávání projektů, uzavření výzvy, jednání výboru (vyřazení a schválení projektů), pozvánka na hlasování nebo informace o vítězných projektech. Veřejnost byla o průběhu plánování a samotném procesu informována především na oficiálním webu města $(3 \mathrm{~h}, 3 \mathrm{i}$, $3 \mathrm{j}, 3 \mathrm{k}$ ), ale také v Semilských novinách (3b, 3c, 3d, 3e) nebo na facebookové stránce města $(3 \mathrm{f}, 3 \mathrm{~g})$. Určitou roli sehrál také zpravodajský portál Naše Pojizeř́, $v$ jehož článcích bylo představeno fungování participativního rozpočtu a důležité informace $(31,3 \mathrm{~m})$.

Do 31. 8. 2015 mohli občané podávat návrhy na financování. Celkem tak bylo podáno 17 návrhů. Politicky a odborně na prrípravu dohlížel Výbor pro rozvoj města (poradní orgán Zastupitelstva města Semily), který pro rok 2016 doporučil (na jednání 27. 10. 2015) k hlasování pouze 13 projektů (4e), načež zbylé čtyři návrhy byly vyřazeny. $\mathrm{V}$ dalším kroku pak byla veřejnost přímo zapojena do výzev, vyhlášení se uskutečnilo 2. 11. 2015 na webu města. Obyvatelé Semil mohli hlasovat pro př́slušné návrhy $\mathrm{v}$ průběhu celého listopadu. Realizovány pak byly pouze čtyři projekty s nejvyšším počtem hlasů (5a). První část třetího kroku kauzálního mechanismu překročila stanovený práh nabytých zkušeností hned v prvním roce. Již od roku 2015 se hlasuje každý rok, protože prvotní zkušenost s participativním rozpočtem byla vyhodnocena i v rámci ČR pozitivně $(5 b)$. Nicméně větší zapojení občanů si místostarosta Tomáš Sábl sliboval až poté, kdy budou první projekty realizovány (5c). Počet hlasujících, a tedy i zájem se mírně zvyšuje (5d) a také se zpřesňují pravidla hlasování (např́íklad byl vyřešen způsob, jak rozhodnout při rovnosti hlasů pro jednotlivé projekty). $\mathrm{V}$ dalších ročnících byla zavedena aplikace mojeID, a tím i hlasování přes internet, což byl výrazný a vůči občanům

Sociológia 52, 2020, č. 2 
Tabulka č. 1: Empirická evidence $\mathbf{k}$ jednotlivým krokům kauzálního mechanismu

\begin{tabular}{|c|c|c|}
\hline $\begin{array}{l}\text { Př́́slušnost evidence } \\
\text { (krok kauzálního } \\
\text { mechanismu) }\end{array}$ & $\begin{array}{l}\text { Identifi- } \\
\text { kátor } \\
\text { evidence }\end{array}$ & Citace či jiná evidence \\
\hline Příčina & 1a & $\begin{array}{l}\text { http://www.volbaprosemily.cz/vyhodnoceni-programu-2014/ } \\
\text { „Umožníme občanům rozhodovat o výdajích části rozpočtu (anketní } \\
\text { hlasování o investicích)““ }\end{array}$ \\
\hline $\begin{array}{l}\text { První krok } \\
\text { mechanismu }\end{array}$ & $2 \mathrm{a}$ & $\begin{array}{l}\text { http://www.volbaprosemily.cz/volebni-program/ } \\
\text { „Participativní rozpočet nadále umožní občanům zvolit investice dle svého } \\
\text { přání.“ }\end{array}$ \\
\hline \multirow[t]{10}{*}{$\begin{array}{l}\text { Druhý krok } \\
\text { mechanismu }\end{array}$} & $3 a$ & $\begin{array}{l}\text { https://www.semily.cz/o-participativni-rozpocet-je-zajem/d-3441 } \\
\text { Výzva byla uveřejněna } 1 \text {. června. Návrhy mohli občané podávat od } 1 . \\
\text { července do } 31 \text {. srpna t.r. a celkem bylo na město doručeno } 17 \text { návrhů. Ty } \\
\text { budou nyní posouzeny pracovníky odboru rozvoje a správy majetku } \\
\text { (ORSM). }\end{array}$ \\
\hline & $3 b$ & $\begin{array}{l}\text { https://www.semily.cz/customers/semily/ftp/File/semilske_noviny/2015/05 } \\
\text { 2015.pdf (str. 5) } \\
\text { „Semilští zastupitelé totiž na svém jednání 20. dubna podpořili návrh } \\
\text { místostarosty Ing. Tomáše Sábla na ustanovení tzv. participativní části } \\
\text { rozpočtu na příśtí rok.“ }\end{array}$ \\
\hline & $3 c$ & $\begin{array}{l}\text { https://www.semily.cz/customers/semily/ftp/File/semilske_noviny/2015/06 } \\
\text { 2015.pdf (str. 2) } \\
\text { „V minulém čísle Semilských novin jste se mohli dočíst, že zastupitelé } \\
\text { schválili participativní část rozpočtu. Nyní se blíže podíváme, co to } \\
\text { znamená.“ }\end{array}$ \\
\hline & $3 d$ & $\begin{array}{l}\text { https://www.semily.cz/customers/semily/ftp/File/semilske_noviny/2015/10 } \\
\text { 2015.pdf (str. 2) } \\
\text { „O participativní rozpočet je mezi občany velký zájem.“ }\end{array}$ \\
\hline & $3 \mathrm{e}$ & $\begin{array}{l}\frac{\text { https://www.semily.cz/customers/semily/ftp/File/semilske_noviny/2015/11 }}{\text { 2015.pdf (str. 2) }} \\
\text { „Participativní rozpočet aneb Rozhodněte o investicích v roce } 2016 . “\end{array}$ \\
\hline & $3 \mathrm{f}$ & $\begin{array}{l}\text { https://www.facebook.com/mesto.semily/photos/a.108923739192644/8921 } \\
\text { 63287535348/?type=3\&theater } \\
\text { „Ještě týden můžete podávat návrhy na drobné investiční akce.“ }\end{array}$ \\
\hline & $3 g$ & $\begin{array}{l}\underline{\text { https://www.facebook.com/mesto.semily/photos/a.108923739192644/9356 }} \\
\frac{\text { 96783181998/?type=3\&theater }}{\text { „Hlasování v anketě bylo ukončeno a zítra proběhne sčítání hlasů.“ }}\end{array}$ \\
\hline & $3 h$ & $\frac{\text { https://www.semily.cz/jak-prosadit-vlastni-investici/d-1221 }}{\text { „Jak prosadit vlastní investici?““ - Zmínky o základních pravidlech. }}$ \\
\hline & $3 \mathrm{i}$ & $\begin{array}{l}\text { https://www.semily.cz/o-participativni-rozpocet-je-zajem/d-3441 } \\
\text { „Participativní rozpočet zatím naplňuje naše očekávání. Návrhy jsou } \\
\text { různého charakteru.“ }\end{array}$ \\
\hline & $3 \mathrm{j}$ & $\begin{array}{l}\text { https://www.semily.cz/rozhodnete-o-investicich-v-roce-2016/d-3776 } \\
\text { „Participativní rozpočet jde do finále a vy můžete v měsíci listopadu vybírat } \\
\text { z navržených investic. Pokud se chcete zapojit do ankety, stačí zajít v } \\
\text { měsíci listopadu na podatelnu ...“ }\end{array}$ \\
\hline
\end{tabular}



hřiště Na Vinici, na místě druhém architektonická soutěž na biotopové koupaliště, následují oprava povrchu Archivní ulice a studie pěšího propojení centra s lokalitou Na Hlínách.“

31 http://www.nasepojizeri.cz/semilsko-aktualne/v-semilech-budou-odrobnych-investicich-rozhodovat-sami-obcane/?aktualitaId=36529 „V Semilech budou o drobných investicích rozhodovat sami občané.“

$3 \mathrm{~m} \quad$ http://www.nasepojizeri.cz/semilsko-aktualne/o-participativni-rozpocet-jev-semilech-zajem/?aktualitaId=38685

4a https://m.semily.cz/assets/File.ashx?id_org=14724\&id_dokumenty=4049 (jednání 25. 3. 2015)

Třetí krok

Návrh „stáhnout z projednávání body 2B) a 3 - mozaika a participativní

mechanismu rozpočet".

4b https://m.semily.cz/assets/File.ashx?id_org=14724\&id_dokumenty=4049 (jednání 20. 4. 2015)

Zastupitelstvo města schvaluje: A) pravidla Participativní části rozpočtu B) objem finančních prostředků na rok 2016 na participativní rozpočtování v celkové výši $1.000 .000 \mathrm{Kč}$

4c https://www.youtube.com/watch?v=im6sz65Qsk\&list=PLY51Xqp_ZA8rBKPAjIYigJEIeK13j-2MW\&index=34 (1h:48min-1h:57min): schválení pravidel participativního rozpočtu a objem peněz pro tuto aktivitu

4d http://alternativazdola.cz/wp-content/uploads/2016/04/SemilyParticipativni_rozpoctovani.pdf

Citace ze zápisu: „Věkovou hranicí od 16 let docílíme většího zájmu mladých lidí o dění ve městě a umožníme jim podílet se na dalším rozvoji města."

4e $\quad$ https://m.semily.cz/assets/File.ashx?id_org=14724\&id_dokumenty=9700 Zdůvodnění vyřazení některých projektů a usnesení: „Výbor pro rozvoj města doporučuje $\mathrm{k}$ zařazení do ankety participativního rozpočtování 13 návrhů dle př́lohy.“

\begin{tabular}{|c|c|c|}
\hline \multirow[t]{5}{*}{ Důsledek } & $5 a$ & $\begin{array}{l}\text { https://investice.semily.cz/projekty/historie/\#year- } 2015 \\
\text { stránka obsahuje přehledný popis jednotlivých projektů, a to včetně } \\
\text { fotografií }\end{array}$ \\
\hline & $5 b$ & $\begin{array}{l}\text { Telefonický rozhovor se starostkou Semil. (5. 12. 2019); vyhodnocení v } \\
\text { ČR, viz https://www.participativni-rozpocet.cz/blog/2017/05/02/uspechy- } \\
\text { participativniho-rozpoctovani-v-cr-v-roce-2016/ } \\
\text { „O aktivitě obyvatel svědčí také množství návrhů, které občané chtějí } \\
\text { z participativního rozpočtu realizovat. V tomto ohledu dopadlo nejlépe } \\
\text { město Semily následováno Zbraslaví, Ostravou-jih a Prahou } 10 . “\end{array}$ \\
\hline & $5 c$ & $\frac{\text { https://www.semily.cz/customers/semily/ftp/File/semilske noviny/2016/02 }}{\text { 2016.pdf (str. 2) }}$ \\
\hline & & $\begin{array}{l}\text { „Osobně jsem věřil, že se do hlasování zapojí víc lidí, ale když vezmeme v } \\
\text { úvahu, že jde o historicky první ročník participativní-ho rozpočtování v } \\
\text { Semilech, není to zase až tak málo. Až občané uvidí, že projekty opravdu } \\
\text { realizujeme, určitě se jich v prríštím roce zapojí mnohem víc.“ (místostarosta } \\
\text { Tomáš Sábl) }\end{array}$ \\
\hline & $5 d$ & $\frac{\text { https://investice.semily.cz/projekty/historie/ }}{\text { Přehled projektů participativního rozpočtu v Semilech včetně fotografí́. }}$ \\
\hline
\end{tabular}

Pozn.: Prezentovány jsou všechny odkazy evidence a z nich vybrané důkazy.

Sociológia 52, 2020, č. 2 
vstřícný krok. Množství pozitivních zkušeností s nástrojem PB a postupné zvyšování jak zájmu a účasti občanů, tak zvyšování kvality a transparentnosti jednotlivých mechanismů podpořily zavedení $\mathrm{PB}$ do standardní obecní praxe. V této fázi lze říci, že participativní rozpočtování ve městě Semily je stabilní a zavedenou součástí místní politiky, čímž byl uzavréen zkonstruovaný kauzální mechanismus.

\section{Závěr}

V našem článku jsme se zaměřili na souvislosti a proces zavádění participativního rozpočtu v obci s rozšiřrenou působností Semily. Město je jedním z mála př́padů $\mathrm{v} \breve{C} \mathrm{R}$, kde zavedení rozpočtu navrhla politická strana, nikoliv zájmová organizace (NSZM). Participativní rozpočet chápeme jako součást zavádění demokratických inovací, které slouží na lokální úrovni k posilování zájmu o veřejné dění a spolupodílení se na správě obce. Představili jsme různé druhy inovativních nástrojů, jak jsou používány, a zaměřili jsme se na participativní rozpočty a jejich ne/rozšiření v České republice a sousedních postkomunistických zemích.

$\mathrm{Na}$ základě metody process-tracing jsme sledovali kauzální mechanismus implementace participativního rozpočtu v Semilech a empirickou evidencí doložili všechny kroky, které vedly k tomu, že můžeme říci, že PB ve městě Semily je stabilní a zavedenou součástí místní politiky na základě prvotního impulzu vzešlého $\mathrm{z}$ dominantní politické strany, která měla zavedení participativního rozpočtu ve svém dlouhodobém programu. Prezentovaný kauzální mechanismus dokládá, že kritickou částí celého procesu je získání bud' přímé či opakované pozitivní zkušenosti s tímto nástrojem, které vede k překročení kvalitativního prahu a zavedení PB do běžné obecní praxe jako nástroje pro rozhodování o distribuci části obecních finančních zdrojů ze strany občanů.

Zhodnocení jednotlivých etap (roků) ukázalo, jakým způsobem byl rozpočet zaváděn, že po skončení první etapy byl zhodnocen a neustále vylepšován, aby ve městě plnil svou funkci. Semily jsou vhodným př́kladem ilustrujícím zavedení a funkčnost participativního rozpočtu. Prezentovaný kauzální mechanismus lze analogicky aplikovat na další př́ipady českých obcí, které splní definované kontextuální podmínky, tzn. existenci politické strany či hnutí, které mají implementaci $\mathrm{PB}$ ve svém volebním či dlouhodobém politickém programu (v prvním př́padě by se $\mathrm{PB}$ mělo objevit $\mathrm{v}$ programovém prohlášení radniční koalice).

Předkládaný článek nabízí hlubší pochopení procesu zavádění $\mathrm{PB}$, částečně i jiných nástrojů demokratických inovací a odkrývá mechanismy a podmínky, které je třeba naplnit, aby bylo možné takové nástroje zavádět i v obcích, které je dosud nevyužívají. Př́ípadová studie ORP Semily ukazuje, jakým způsobem 
vypadá inkluzivní a intenzivní charakter zavedení a využívání konkrétní demokratické inovace.

Markéta Zapletalová působi jako odborná asistentka na Katedře politologie a evropských studií FF UP. Zabývá se problematikou institucí Evropské unie, kvality demokracie a italskou politikou. V současné době zpracovává projekt, který se věnuje současnými trendy politického marketingu.

Michal Soukop absolvoval magisterský studijní program politologie na Filozofické fakultě Univerzity Palackého v Olomouci, kde nyni pokračuje $v$ doktorském programu. Zaměřuje se predevšim na výzkum občanského vzdělávání, demokratických inovaci a lokálni politiky. Je spoluautorem několika odborných statí z tèchto tematických oblastí.

Pavel Šaradín působi jako docent na Katedře politologie a evropských studii FF UP v Olomouci. Ve svých výzkumných aktivitách se věnuje zejména problematice kvality demokracie, lokální politice a politickému systému $\check{C} R$. Publikuje v odborných časopisech a monografiích. V posledni době byl ř řsitelem či spoluřešitelem řady vědeckých projektů, které se věnovaly predevším demokratickým inovacim, občanskému vzděláváni či volebním chybám a podvodům.

\section{LITERATURA}

ABERS, R., 1998: From Clientelism to Cooperation: Local Government, Participatory Policy, and Civic Organizing in Porto Alegre, Brazil. Politics \& Society 26, č. 4, 511-537. Dostupné z: https://journals.sagepub.com/doi/10.1177/0032329298026004004

Agora Central Europe, 2018: Participativní rozpočty v České republice v roce 2018. Participativní rozpočet. Dostupné z: https://www.participativni-rozpocet.cz/blog/ 2019/03/11/participativni-rozpocty-v-ceske-republice-v-roce-2018/

ALLEGRETTI, G. - ANTUNES, S., 2014: The Lisbon Participatory Budget: Results and Pespectives on an Experience in Slow but Continuous Transformation. Field Actions Science Reports. The Journal of Field Actions, č. 11. Dostupné z: https://journals.openedition.org/factsreports/3363\#text

AVRITZER, L., 2002: Democracy and the Public Space in Latin America. Princeton: Princeton University Press.

BAIOCCHI, G. - GANUZA, E., 2016: Popular Democracy: The Paradox of Participation. Stanford: Stanford University Press.

BALÍK, S., 2008: Česká komunální politika v obcích s rozšířenou působností: Koalice, voličské vzorce a politické strany na místní úrovni v letech 1994 - 2006. Brno: Centrum pro studium demokracie a kultury.

BEACH, D. - PEDERSEN, R. B., 2018: Selecting Appropriate Cases When Tracing Causal Mechanisms. Sociological Methods \& Research 47, č. 4, s. 837-871.

BEACH, D. - PEDERSEN, R. B., 2019: Process-Tracing Methods: Foundations and Guidelines. Michigan: University of Michigan Press.

Sociológia 52, 2020, č. 2 
BEDNARSKA-OLEJNICSAK, D. - OLEJNICSAK, J., 2018: Participatory Budgeting in Poland in 2013 - 2018 - Six Years of Experiences and Directions of Changes. In: Dias, N. (ed.): Hope For Democracy. 30 Years of Participatory Budgeting Worldwide. Epopeia Records/Oficina, s. 337-354.

BENNETT, A. - CHECKEL, J. T. (eds), 2014: Process Tracing: From Metaphor to Analytical Tool. Cambridge: Cambridge University Press.

BUREŠOVÁ, B. - BALÍK, S., 2019: Kdo jsou iniciátoři místních referend v ČR? Acta Politologica 11, č. 2, s. 18-38. Dostupné z: https://acpo.vedeckecasopisy.cz/publicFiles/001747.pdf

ČERMÁK, D. - STACHOVÁ, J., 2007: Občanská participace na lokální úrovni. In: Nejdl, P. - Čermák, D. (eds.): Participace a partnerství v místní veřejné správě. Praha: Sociologický ústav AV ČR, s. 94-114. Dostupné z: https://www.soc.cas.cz/sites/default/files/publikace/2007-10_5.pdf

DIAS, N. (ed.), 2014: Hope for Democracy - 25 Years of Participatory Budgeting Worldwide. Dostupné z: http://www.in-loco.pt/upload_folder/edicoes/1279dd27-d1b1-40c9-ac77c75f31f82ba2.pdf

ELSTUB, S. - ESCOBAR, O., 2017: A Typology of Democratic Innovations. Paper for the Political Studies Association's Annual Conference, 10t-12th April, Glasgow. Dostupné z: https://www.psa.ac.uk/sites/default/files/conference/papers/2017/A\%20Typology\% 20 of\%20Democratic\%20Innovations \%20$\%$ 20Elstub\%20and\%20Escobar\%202017.pdf

GEISSEL, B., 2009: How to Improve the Quality of Democracy? Experiences with Participatory Innovations at the Local Level in Germany. German Politics and Society 27, č. 93 (No. 4 Winter 2009), s. 53.

GOLDFRANK, B., 2012: The World Bank and the Globalization of Participatory Budgeting. Journal of Public Deliberation 8, č. 2. Dostupné z: https://www.publicdeliberation.net/jpd/vol8/iss2/art7

GRET, M. - SINTOMER, Y., 2005: The Porto Alegre Experiment. Learning Lessons for a Better Democracy. London: Zed-Books.

HELLER, P., 2001: Moving the State: The Politics of Democratic Decentralization in Kerala, South Africa, and Porto Alegre. Politics \& Society 29, č. 1 (March), s. 131 163.

HERNÁNDEZ-MEDINA, E., 2007: Globalizing Participation: 'Exporting' the Participatory Budgeting Model from Brazil to the Dominican Republic. Berkeley Journal of Sociology 51, s. 69-118.

HRABINOVÁ, A., 2018: Metodika hodnotenia procesov participatívneho rozpočtovania pre mapovanie skúseností s participatívnym rozpočtovaním v prostredí miestnej územnej samosprávy na Slovensku. Dostupné z:

https://www.minv.sk/swift_data/source/rozvoj_obcianskej_spolocnosti/participacia/ vystupy_np_parti/Metodika\%20hodnotenia\%20procesov\%20participativneho\%20r ozpoctovania_Alexandra\%20Hrabinova.pdf

HURTÍKOVÁ, H. - SOUKOP, M., 2019: Participative and Deliberative Democracy on the Local Level: How the Political Characteristics of Municipalities in the Czech 
Republic Relate to the Use of Selected Democratic Innovation within their Territory? Lex localis - Journal of Local Self-Government 17, č. 2, s. 369-393.

KĘBŁOWSKI, W. - VAN CRIEKINGENB, M., 2014: Participatory Budgeting Polishstyle. What kind of Policy Practise Travelled to Sopot, Poland? In: Dias, N. (ed.): Hope For Democracy - 25 Years of Participatory Budgeting Worldwide, s. 369377.

KLIMOVSKÝ, D., 2017: Case study 1: Participatory Budgeting in Slovakia: Experience from Bratislava and Ružomberok. In: Klimovský, D. (ed.): Participatory budgeting. Capacity Buildingof NAPA for Open Local Governance, s. 16. Dostupné z:

http://www.nispa.org/files/publications/training/Participatory_budgetingENG.pdf

KRENJOVA, J. - RAUDLA, R., 2013: Participatory Budgeting at the Local Level: Challenges and Opportunities for New Democracies. Halduskultuur - Administrative Culture 14, č. 1, s. 18-46. Dostupné z:

https://www.oidp.net/docs/repo/doc624.pdf

LAŽOVÁ, E., 2017: E-Participace v místní veřejné správě. Ostrava: VŠB-TU. Dostupné z: https://dspace.vsb.cz/bitstream/handle/10084/118130/LAZ0046_EKF_ B6202_6202R055_2017.pdf? sequence $=1$ \&isAllowed $=$ n

MAZÁK, J., 2017: Process tracing: zkoumání kauzality v př́ípadových studiích. Sociológia 49, č. 1, s. 55-80.

MOTYČKOVÁ, K., 2018: Srovnání modelů participativního rozpočtování ve vybraných městech ČR. Brno: Masarykova univerzita. Dostupné z: https://is.muni.cz/th/o75bg/Diplomova_prace_Katerina_Motyckova.pdf

NEWTON, K., 2012: Curing Democratic Malaise with Democratic Innovations. In: Geissel, B. - Newton, K. (eds): Evaluating Democratic Innovations. Curing the Democratic Malaise. NY and London: Routlege, s. 4-5.

PINNINGTON, E. - LERNER, J. - SCHUGURENSKY, D., 2009: Participatory Budgeting in North America: The Case of Guelph, Canada. Journal of Public Budgeting, Accounting \& Financial Management 21, č. 3, s. 455-484.

PIŠKO, M., 2018: Otvorená samospráva 2018 - Analýza transparentnosti 100 najväčších miestnych samospráv na Slovensku. Bratislava: Transparency International Slovensko. Dostupné z: http://cms.transparency.sk/wpcontent/uploads/Anal\%C3\%BDza_Rebr\%C3\%AD\%C4\%8Dek-transparentnostimiest-20181.pdf

RAZA, A. - THÉBAULT, W. E., 2006: Fostering Public Participation in Budgetmaking. Case Studies from Indonesia, the Marshall Islands, and Pakistan. Manila: $\mathrm{ADB}$ and The Asia Foundation.

ROMA CAPITALE, 2019: Bilancio Partecipativo di Roma Capitale 2019. Dostupné z: https://www.comune.roma.it/web/it/processo-partecipativo.page?contentId=PRP 322060

RÖCKE, A., 2014: Framing Citizen Participation - Participatory Budgeting in France, Germany and the United Kingdom. Palgrave Macmillan.

SANTOS, B. de S., 1998: Participatory Budgeting in Porto Alegre: Towards a Redistributive Democracy. Politics \& Society 26, č. 4 (March), s. 461-510.

SHAH, A. (ed.), 2007: Participatory Budgeting. New York: The World Bank. 
SINTOMER, Y. - HERZBERG, C. - RÖCKE, A., 2008: Participatory Budgeting in Europe: Potentials and Challenges. International Journal of Urban and Regional Research 32.1, March, s. 164-178.

SINTOMER, Y. - HERZBERG, C. - RÖCKE, A., 2013. Participatory Budgeting Worldwide - Updated version. Study, no. 25. Bonn: Engagement Global.

SINTOMER, Y. - HERZBERG, C. - RÖCKE, A., 2016: Participator Budgeting in Europe. Democracy and Public Governance. London and New York: Routledge.

SIPOS, M. - RESZKETÖ, P. E., 2019: Budapest Participatory Budget, Case Study Report. Participatory Budgeting for Sustainable Development of V4 Capital Cities. Dostupné z: https:/www.participativni-rozpocet.cz/wpcontent/uploads/2019/03/REPORT_BUDAPEST-PB.pdf

SMITH, M. L., 2006: Cesty k efektivní př́mé demokracii: česká místní referenda v regionálním srovnání. Politologický časopis 4, s. 399-422. Dostupné z: http://www.politologickycasopis.cz/userfiles/file/2006/4/Polcas_2006_4_pp_399_4 22.pdf

SMITH, M. L., 2009: Občané v politice: Studie k participativní a prŕmé demokracii ve střední Evropě. Praha: ISEA - Institut pro sociální a ekonomické analýzy.

ŠMERDOVÁ, V., 2016: Prvky deliberativní demokracie v ČR: př́padová studie participativního rozpočtu v městské části Praha 10. Praha: Univerzita Karlova.

VÍTKOVÁ, T., 2014: Participativní rozpočtování. Brno: Masarykova univerzita. Dostupné z: https://is.muni.cz/th/z8kkk/Participativni_rozpoctovani.pdf

VOJTÍŠKOVÁ, K., 2016: Česká cesta k participativnímu rozpočtování. Smart Cities 2, 2016, s. 98-100. Dostupné z: https://www.scmagazine.cz/casopis/02-16/ceskacesta-k-participativnimu-rozpoctovani_locale_cs/

WAMPLER, B., 2007: A Guide to Participatory Budgeting. In: Shah, A. (ed.): Participatory Budgeting. New York: The World Bank, s. 21-54.

WAMPLER, B. - MCNULTY, S. - TOUCHTON, M., 2018: Participatory Budgeting: Spreading Accross the Globe. Dostupné z: https:/www.transparencyinitiative.org/wp-content/uploads/2018/03/spreading-pb-across-the-globe_jan2018.pdf

WISNIEWSKA, M., 2018: Budżet obywatelski w polskich miastach -doświadczenia w województwie łódzkim. Studia Miejskie 29, s. 91-99. Dostupné z: http://www.studiamiejskie.uni.opole.pl/wpcontent/uploads/2018/09/S_Miejskie_29_2018-Wisniewska.pdf 